\title{
Colonisation by fragments in six common aquatic macrophyte species
}

\author{
Ágnes Vári
}

With 3 figures and 6 tables

\begin{abstract}
Vegetative reproduction is the most common form of propagation in aquatic macrophytes. Fragmentation and consecutive re-rooting of the fragments is one way in which new macrophyte colonies may establish. The success and frequency of this strategy depends on the species and the environment. This study tested how well six species are capable of colonising this way. Tested species are five of the most abundant species of Lake Balaton, where macrophyte recolonisation is still to take place after improving water quality and one potentially invasive species. Fragments of standardized length were examined for survival, rooting rates and length growth during five to six week experiments under laboratory conditions. Effects of species, shoot part (apical or mid-stem part) and seasonality on rooting probability were analysed with logistic regression. Effects on life-cycle were also examined, in terms of continuation of growth and of flowering or seed-set. Species differed significantly in rooting rates and growth, but not in survival rates. Egeria densa, Myriophyllum spicatum and Potamogeton perfoliatus showed the best colonisation properties (survival rates: $95 \%, 84 \%$ and $84 \%$; rooting rates: $88 \%, 45 \%$ and $65 \%$, respectively), while Potamogeton pectinatus colonised less successfully (survival rate: $91 \%$, rooting rate: $38 \%$ ). The annual Najas marina was the only species which frequently reached flowering $(61 \%)$, while fragmenting further, without much rooting (rooting rate: $5 \%$ ). The non-rooting Ceratophyllum demersum was least impacted by fragmentation and continued growth best, with survival rates of $100 \%$. Shoot part had a significant influence on rooting rate and length growth. Apical fragments had higher rooting rates and greater length growth than stem fragments, probably due to the action of their meristematic tissue. Differences in the three repetitions of the experiment may be attributable to seasonal changes in colonisation features. It is concluded that recolonisation by fragments might be an effective way for macrophyte populations to recover in Lake Balaton.
\end{abstract}

Key words: macrophyte, survival, rooting, growth, apical meristem, life-cycle, seasonal pattern.

\section{Introduction}

Macrophytes have several ways of propagation, which often occur in combination (Arber 1920, Hutchinson 1975, Barrat-Segretain 1996). Nevertheless, vegetative propagation dominates in most cases, while sexual reproduction is often limited (Borbás 1900, Arber 1920, Barrett et al. 1993, Barrett et al. 1996, Kautsky 1990). Vegetative reproduction - including clonal growth as well as propagation by several asexual propagules - is an especially effective way of propagation in aquatic environments as the dispersal of vegetative propagules is facilitated by water convection. Water also protects propagules from desiccation and permits the transport of relatively heavy structures compared to the airborne lightweight seeds more common in terrestrial plants (Kautsky 1988, Preston 1995, Silvertown 2008). This applies also to non-specialized propagules originating from the vegetative parts of the plants. Propagation by fragment colonisation is a mode of clonal reproduction

\section{Author's address:}

Balaton Limnological Institute, Centre for Ecological Research, Hungarian Academy of Sciences, 8237 Tihany,

Klebelsberg K. u. 3, Hungary

agnesvari@yahoo.com

Present address: Yggdrasil Diemer environmental consultancy, 10965 Berlin, Dudenstr. 38, Germany 
that is mainly used by aquatic clonal plants, whereas in terrestrial environments it occurs much less frequently (Grace 1993). Shoot fragments can be formed by external forces such as wave action, animal feeding and dislodging or human activity. Some species, e.g. Myriophyllum spicatum L. tend to autofragment, which was known many years ago (Arber 1920, Borbás 1900), and confirmed by more recent research (Aiken et al. 1979, Hartleb et al. 1993, Kimbel 1982, Xie $\&$ Yu 2011). As the fragments stay in a life-supporting environment (water), there is always the possibility of developing new adventitious roots and/or re-growing into complete plants. This has been shown for some aquatic species. Aiken et al. (1979) describe that detached M. spicatum shoots often develop roots before sinking to the sediment. The formation of adventitious roots also helps survival by enhancing uptake of nutrients from the water column (Wersal \& Madsen 2011).

As shoot fragments float freely, water facilitates survival as well as dispersal (Grace 1993), thereby further distances can be covered than by rhizomatic growth. The potential for long-distance dispersal makes fragmentation similar to sexual reproduction (Wiegleb \& Brux 1991). It is an especially successful way of dispersal and regeneration under habitat conditions which involve frequent disturbance (BarratSegretain et al. 1998, Grace 1993, Wiegleb \& Brux 1991). Most research on this topic is therefore conducted in rivers or flood plains (Barrat-Segretain et al. 1998, 1999, Capers 2003, Riis 2008, Umetsu et al. 2012), while less is known about its importance in the comparatively undisturbed habitats of lakes (but see Madsen et al. 1988, Kimbel 1982). It is known that populations in different habitats might develop different life-histories, i.e. rely more on certain reproductive strategies than on others (van Wijk 1989).

In some cases certain species have used this method of dispersal very successfully, for example the rapid spread of M. spicatum and its development into a nuisance plant in North-America is thought to be based on its aptitude to fragment and regenerate from fragments (e.g. Nichols \& Shaw 1986) as is the spread of Elodea canadensis L. in the $20^{\text {th }}$ century in Europe (Hutchinson 1975). All this shows that reproduction via unspecialized vegetative fragments is a process of great ecological significance.

The success of reproduction by fragmentation strongly depends on the species and not all species are capable of colonizing via fragments (Barrat-Segretain et al. 1998, Riis et al. 2009, Umetsu et al. 2012). The degree to which a species (or a plant in a certain habitat) is able to colonize by fragments might also depend on how well it is adapted to surviving without roots. If it relies mainly on nutrient supply via its roots, abscission from the main plant will probably have more severe effects than it would on plants which also take up nutrients from the water column. Obviously, Ceratophyllum demersum L. is not dependent on nutrients taken up by roots from the sediment as it forms hardly any roots (Denny 1972). A number of other species also satisfy all their nutrient needs via leaf uptake alone (Madsen \& Cedergreen 2002), including M. spicatum (Cao \& Wang 2012b). With highly dissected leaves, a much greater surface is available for nutrient uptake from the water compared to entire leaf shapes.

Thus, for some species fragmentation might be part of their normal life-cycle and contribute to their dispersal (M. spicatum, and also the non-rooting C. demersum L., Arber 1920). If fragmentation does not impede the normal life cycle, then fragments should follow life-history in the same way as if rooted, i.e. they should complete flowering and fructification and carry on with shoot growth. Therefore, the hypothesis is tested that species better adapted to a rootless state (i.e. with highly dissected leaves, rhizoids instead of roots) will show higher survival rates and will continue better their life-cycle (including growing shoots and/or building flowers) after fragmentation.

While there are obvious differences between species in their capability to colonize from shoot fragments, there might also be differences within plants, depending on which plant part was abscised (BarratSegretain 1999, Riis et al. 2009). Fragments might include subterranean plant parts (mostly rhizomes), or shoots with apical tips, or only shoots. Effects of shoot part were found for example for Potamogeton perfoliatus L., Egeria densa Planch. and sometimes for M. spicatum, where apices generally had an increasing effect on growth and colonisation (Riis et al. 2009). Therefore, if species colonisation features are to be examined, different shoot parts with and without apices need to be included.

Many studies describe seasonal patterns in macrophyte population growth (Madsen et al. 1988, Sayer et al. 2010, Tóth \& Herodek 2011), but only a few take seasonal effects into account when examining colonisation capabilities of different species (BarratSegretain \& Bornette 2000). The present study was designed to cover three seasons in order to be able to detect seasonal differences.

The question of how far shoot fragments can contribute to the propagation of different macrophyte species is also of specific interest in Lake Balaton. Lake Balaton has experienced a period of intense eutrophication 
from the 1960s onwards. Aquatic vegetation peaked between 1960 and 1970 (Kárpáti 1980) with P.perfoliatus dominating most macrophyte patches, producing $80 \mathrm{~g} / \mathrm{m}^{2}$ (dry weight; Kárpáti \& Varga 1970). However, extreme eutrophication in the 1970s resulted in collapsing macrophyte populations (Herodek \& Lackó 1988). By 1978 an estimated area of about $1.1 \%$ of the lake was covered with macrophytes (Juhász 1981), which was four times less than in 1976 (Virág 1998). Measures were taken during the 1980s in order to improve water quality (e.g. reduction of nutrient inflow by the development of wastewater treatment, reduction of internal load by dredging) (Herodek \& Lackó 1988), which resulted in re-oligotrophication of Lake Balaton, by which the Lake returned to a mesotrophic to eutrophic state (Istvánovics et al. 2007, Présing et al. 2007). Even though lake water quality improved substantially, submerged lake vegetation is still sparse and significant re-establishment has yet to take place. Therefore, one major aspect of this study was to assess the potential for colonisation via fragments of the main species occurring in Lake Balaton, taking different, possibly influential factors into account.

In order to examine species-specific effects as well as factors influencing rooting success, a series of experiments was set up, to find out how species differ in their abilities of colonising by fragment rooting. I wanted to test whether there are differences between (i) species, (ii) seasons, (iii) shoot parts in (iv) survival rates, (v) rooting rates or (vi) length growth.

\section{Material and methods}

In a laboratory experiment the ability of six species (Ceratophyllum demersum, Egeria densa, Najas marina L., Myriophyllum spicatum, Potamogeton pectinatus L. and P. perfoliatus) to grow further after fragmentation, build flowers and fruits and root into the underlying sediment was examined using shoot pieces of a standardized length. The experiment was repeated three times (in spring, summer and autumn). For three species (M. spicatum, P.pectinatus, P. perfoliatus) the effect of seasonality was tested. The rooting activity of three species was examined regarding the effect of shoot parts (E. densa, M. spicatum, P. perfoliatus).

Shoot apices and shoot mid-parts (stems) of $15 \mathrm{~cm}$ length were cut from plants collected freshly in Lake Balaton, were individually tagged and placed at random into three pans $(53 \mathrm{~cm} \times 62 \mathrm{~cm})$ each filled with $1 \mathrm{~cm}$ of pebbles and $1 \mathrm{~cm}$ of lake sediment above which $7 \mathrm{~cm}$ of lake water was added. Fragments were cut at fixed lengths in order to enable a better comparison of species regarding a field situation in which waves break the plants at certain heights, independent of node numbers included in that fragment. The standard length of $15 \mathrm{~cm}$ was supposed to provide sufficiently high probabilities of rooting (based on preliminary experiments and also supported by the description given by Smith et al. (2002) for allofragments).
In the first series 30 fragments were used per species (altogether 90 fragments), while in the second and third series 20 fragments were used for each species (altogether 100 fragments). For a period of five-six weeks, they were examined weekly, rooting into sediment checked, their length measured and plants examined for inflorescences. Water was exchanged and fragments re-distributed in a random manner in the pans in order to avoid position effects. Rooting was defined as the growth of roots into the sediment, whereas survival was defined either as floating in an unrooted but vital state in the water till the end of the experiment or as rooting before the end of the experiment as rooted plants were likely to survive. Once plants rooted they were removed from the pans to exclude competition. If shoots fragmented further, the new fragment was tagged as well and followed as a new plant. This was done in order to include the possible effect of further fragmentation on the chances of colonisation.

Pans were kept under semi-controlled conditions, light and temperature was checked continuously and nutrient conditions regularly on a bi-weekly basis. Light was provided by natural (windows) and artificial sources (two fluorescent white light tubes about $50 \mathrm{~cm}$ above the pans) at a constant light period of $15 \mathrm{~h}$ a day. While nutrient conditions did not differ significantly (ANOVA, $p>0.05$, mean values $\pm \mathrm{SE}: \mathrm{NO}_{3}-\mathrm{N} 98.8 \pm 11.2 \mu \mathrm{g}$ $1^{-1}, \mathrm{NH}_{4}-\mathrm{N} 3.5 \pm 0.8 \mu \mathrm{g} \mathrm{l}^{-1}, \mathrm{PO}_{4}-\mathrm{P} 15.0 \pm 2.6 \mu \mathrm{g} \mathrm{l}^{-1}$ ), light intensity and temperature values were significantly different (both ANOVA, $p<0.001$, with mean values of $22.6 \pm 0.1^{\circ} \mathrm{C} \mathrm{SE}$ and $87.8 \pm 2.3 \mu \mathrm{mol} \mathrm{m} \mathrm{m}^{-2} \mathrm{~s}^{-1}$ and series 1 and 2 differing, Tukey's post-hoc, $p<0.001)$. However, for temperature, this is likely of no ecological relevance, as variance in the temperature data was altogether very low, with series mean temperatures of $22.5^{\circ} \mathrm{C}, 23.0^{\circ} \mathrm{C}$ and $22.1^{\circ} \mathrm{C}$ most probably not being ecologically distinct. Effects of different light intensities (series 1: $77.8 \pm 20.7 \mu \mathrm{mol} \mathrm{m}^{-2} \mathrm{~s}^{-1}$, series 2: $97.5 \pm 20.8 \mu \mathrm{mol} \mathrm{m}^{-2} \mathrm{~s}^{-1}$, series 3: $85.4 \pm 19.3 \mu \mathrm{mol} \mathrm{m}^{-2} \mathrm{~s}^{-1}$, mean $\pm \mathrm{SD}$ ) might be conceivable (see Discussion).

The first series was set up on the $22^{\text {nd }}$ May 2008 with the three main species occurring in Lake Balaton, P.perfoliatus, P.pectinatus and M. spicatum. After six weeks (on $3^{\text {rd July }}$ 2008), when most plants had either rooted or showed signs of degeneration, the second run was started with the same specifications but including Ceratophyllum demersum, another frequent species of Lake Balaton and Egeria densa, which occurs in an inflowing warm water channel. This summer experiment lasted for five weeks. The third, autumn repetition started on the $7^{\text {th }}$ August 2008, lasted five weeks and included another species frequently encountered in the lake, Najas marina, in place of C. demersum.

Growth was defined as growth in length, therefore growth rate was calculated based on shoot lengths measured once a week (length growth / time).

For calculating survival or rooting rate, fragments formed during the experiment were also included: the number of all fragments that survived (or rooted) - no matter whether from the start or produced meanwhile - were divided by the number of all shoots (those at start and those fragmented during the experiment). Data from new fragments were included as this constitutes also an important part of the biomass allocation of the plant. A fragmentation index was calculated by dividing the number of fragments built during the experiment by the number of fragments at the start. Minimum mean survival time was calculated only for shoots from the start as an approximation for the duration of survival: the duration of the respective experi- 
mental series was taken as the survival time for all fragments rooted meanwhile (and hence removed) and for all surviving without rooting till the end of the experiment.

For making comparisons easier, data are shown in percentages (number of shoots survived or rooted divided by total number of shoots in the experiment). For statistical analyses the absolute numbers of shoots (for Chi-square tests) or all occurrences of survival or rooting (for logistic regression) were used. The dataset for analysing the effect of seasonality included all shoot data of the three species used in all three repetitions (M.spicatum, P.pectinatus, P.perfoliatus), while the effect of shoot part was tested on data from species with definite shoot apex and stem parts (E.densa, M. spicatum, P. perfoliatus).

Data analysis was performed in R 2.14.2 (R Development Core Team 2012), using logistic regression analysis for testing the effects of species and seasonality and of species and shoot parts on the probability of survival and colonisation (rooting). The variable not focused on was still included in the analyses in order to account for possible confounding effects. Differences in the number of survived or rooted shoots were tested pairwise between species with Chi-square tests. Differences in species rooting times were analysed with Kruskal-Wallis test and pairwise differences with Mann-Whitney-Wilcoxon tests. For calculating peakedness of the rooting time distribution, kurtosis was measured with the R package "e1071" (Meyer et al. 2012). For analysis of the effect of shoot part and species on shoot length growth, data from fragments on the second week of the experiments was used, as at this stage differences (if present) were already likely to occur, but not many shoots were rooted yet and therefore numbers for statistical analyses were still high enough. Analysis of variance was performed with Tukey's posthoc test to identify differences between species.

\section{Results}

Colonisation characteristics of the species examined differed significantly in several features of survival and rooting. In general, survival rates ranged from 83 to $100 \%$ on average, with $C$. demersum and E. densa at the top of the range and N. marina and P.perfoliatus at the bottom, but not showing any statistically significant differences $\left(X^{2}\right.$-test over all species: $X^{2}(5)=$ 1.91, $p>0.05$; survival rates see Table 1). Survival of the initially introduced fragments was to some extent always complemented by vegetative reproduction. This is shown as a fragmentation index, calculated as the ratio of newly built fragments to initial fragments (Table 1). Mean minimum survival times were between 4.5 and 5.2 weeks for the different species, with $N$. marina and P. pectinatus showing lowest and highest survival times, respectively (Table 1). N. marina survival time differed significantly from all the other species, while P.pectinatus differed only from C. demersum, E. densa and N. marina.

Testing the effects of shoot part on survival with logistic regression showed no significant differences between species. The effect of season on survival probability was significant $(p<0.01)$ with odds being 25.8 times and 4.0 times higher for surviving in summer or autumn, respectively, compared to surviving in spring.

Table 1. Survival rates of the investigated species after five to six weeks for the three repetitions, means (weighted with the total number of shoots per series) \pm standard deviation, fragmentation index (ratio of new shoots / shoots from the start) and minimum mean survival time (duration of series taken as survival time for rooted fragments and for fragments alive but non-rooted at the end).

\begin{tabular}{|c|c|c|c|c|c|c|}
\hline & \multicolumn{4}{|c|}{ Survival rate } & \multirow{2}{*}{$\begin{array}{l}\text { Fragmentation } \\
\text { index }\end{array}$} & \multirow{2}{*}{$\begin{array}{c}\text { Survival time } \\
\text { [weeks] }\end{array}$} \\
\hline & series 1 & series 2 & series 3 & mean $\pm \mathrm{SD}$ & & \\
\hline C. demersum & & $100 \%$ & & $100 \%$ & 0.3 & $5.0 \pm 0.0$ \\
\hline E. densa & & $100 \%$ & $100 \%$ & $100 \pm 0 \%$ & 0.3 & $5.0 \pm 0.0$ \\
\hline M. spicatum & $74 \%$ & $97 \%$ & $88 \%$ & $84 \pm 11 \%$ & 0.4 & $4.8 \pm 1.5$ \\
\hline N. marina & & & $83 \%$ & $83 \%$ & 1.1 & $4.5 \pm 1.2$ \\
\hline P.pectinatus & $93 \%$ & $100 \%$ & $90 \%$ & $95 \pm 5 \%$ & 0.1 & $5.2 \pm 1.0$ \\
\hline P.perfoliatus & $65 \%$ & $100 \%$ & $95 \%$ & $84 \pm 19 \%$ & 0.1 & $5.1 \pm 0.9$ \\
\hline
\end{tabular}

Table 2. Rooting rates of the investigated species after five to six weeks for the three repetitions and averaged (weighted with the total number of shoots per series) for all shoots. "start" and "new" show rooting rates (weighted averages) of fragments introduced at the start of the experiment and of fragments produced during the experiment.

\begin{tabular}{|c|c|c|c|c|c|c|}
\hline & series 1 & series 2 & series 3 & mean $\pm \mathrm{SD}$ & start & new \\
\hline C. demersum & & $0 \%$ & $0 \%$ & $0 \pm 0 \%$ & $0 \%$ & $0 \%$ \\
\hline E. densa & & $87 \%$ & $90 \%$ & $88 \pm 3 \%$ & $100 \%$ & $73 \%$ \\
\hline M. spicatum & $17 \%$ & $69 \%$ & $67 \%$ & $45 \pm 29 \%$ & $61 \%$ & $16 \%$ \\
\hline N. marina & & & $5 \%$ & $5 \%$ & $10 \%$ & $0 \%$ \\
\hline P.pectinatus & $10 \%$ & $52 \%$ & $62 \%$ & $38 \pm 28 \%$ & $39 \%$ & $33 \%$ \\
\hline P.perfoliatus & $32 \%$ & $81 \%$ & $95 \%$ & $65 \pm 33 \%$ & $69 \%$ & $71 \%$ \\
\hline
\end{tabular}


The percentage of fragments of different species developing roots and anchoring with these in the sediment after five-six weeks is shown in Table 2. E. densa and P. perfoliatus are the most successful species, followed by $M$. spicatum and further by P. pectinatus (difference between P.perfoliatus - E. densa and P.perfoliatus - M. spicatum: $p>005$; between M. spicatum - E. densa: $p<0.001 ; \mathrm{X}^{2}$-tests). N. marina showed only very limited rooting activity ( $5 \%$, corresponding to two individuals rooting), and C. demersum was not observed to build any typical rhizoid structures. Due to this distinctly different rooting behaviour, these two species were disregarded in further analyses of rooting characteristics.

Differences in rooting rates between the seasons could be best assessed for species with three repetitions, one each in spring, summer and autumn (M. spicatum, P.pectinatus, P.perfoliatus). Using this dataset for logistic regression experiment, season shows a significant effect on the probability of rooting with the second and the third series (summer and autumn) differing mainly from the first (spring) series (both at $p<0.001$; Table 2, Fig. 1). The odds ratio of rooting in summer or autumn was 15.4 and 25.9 times higher than for rooting in spring. Differences between the species were also significant, with P. pectinatus being distinct from P. perfoliatus and M. spicatum $(p<0.001)$. However differences were minor, as the odds for rooting of
P. pectinatus were 0.1 times less than for M. spicatum (and 1.6 times higher for P. perfoliatus).

Using the dataset with E. densa, M. spicatum and $P$. perfoliatus for testing effects of shoot parts on rooting probability with logistic regression, shoot part was shown to have a significant effect on rooting probabilities ( $p<0.01$ ), with odds being 0.3 times lower for rooting of stem parts. No significant differences were detected between the rooting rates of these three species.

The colonisation rate of new fragments is for most species almost as high as for the shoots introduced at the beginning: most differences were not significant (pairwise $\mathrm{X}^{2}$-tests, $\mathrm{p}>0.05$; survival rates see Table 2). Only new shoot fragments of M. spicatum showed much less rooting than shoots from the start $(16 \%$ compared to $61 \%$ ), which was highly significant $\left(\mathrm{X}^{2}(1)=8.50, p<0.01\right)$.

Most shoots rooted between the second and the third week after the start of the experiment (Table 3). Only E. densa started to root before the second week. Examining the distribution of rooting times (Fig. 2) shows that all distributions are skewed, peaking at earlier weeks, with more or less extended tails to the right, showing some rooting in later weeks too. The peakedness shows how concentrated rooting activity of the single species was. This can be quantified by kurtosis, with more negative values indicating a flatter

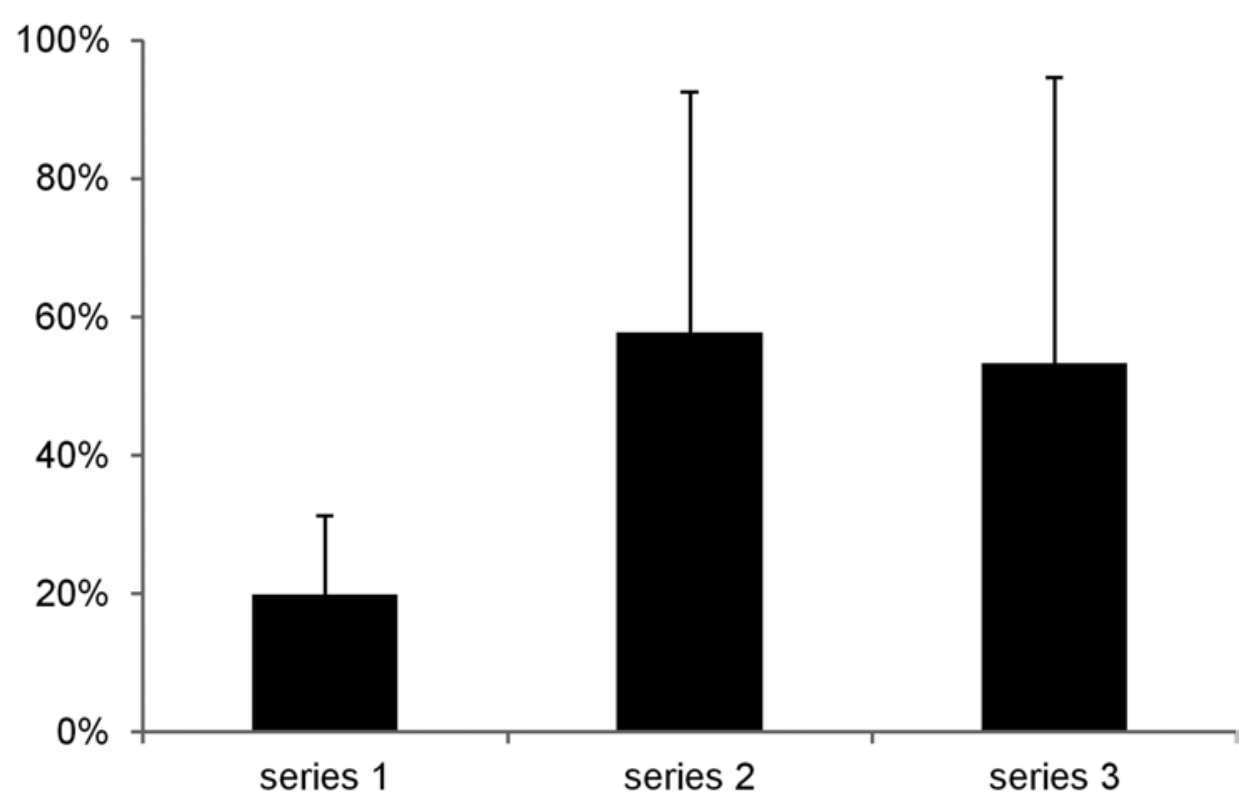

Fig. 1. Rooting rates of the six tested species after five to six weeks in the different experimental series. Differences between series 1 (spring) - series 2 (summer) and series 1 - series 3 (autumn) are significant for the species tested in all three repetitions (Myriophyllum spicatum, Potamogeton pectinatus and Potamogeton perfoliatus) at $p<0.001$ (logistic regression). 
Table 3. Rooting time of the investigated species after five to six weeks for the three repetitions and as average (weighted with the total number of shoots per series).

\begin{tabular}{|c|c|c|c|c|c|c|}
\hline & \multicolumn{4}{|c|}{ rooting time [weeks] } & \multirow[b]{2}{*}{ median } & \multirow[t]{2}{*}{ kurtosis } \\
\hline & series 1 & series 2 & series 3 & mean $\pm \mathrm{SD}$ & & \\
\hline \multicolumn{7}{|l|}{ C. demersum } \\
\hline E. densa & & 2.0 & 2.6 & $2.3 \pm 0.8$ & 2 & -0.1 \\
\hline M. spicatum & 2.0 & 2.3 & 2.7 & $2.4 \pm 0.6$ & 2 & -0.6 \\
\hline N. marina & & & 2.0 & 2.0 & 2 & $*$ \\
\hline P.pectinatus & 6.0 & 3.6 & 3.3 & $3.7 \pm 1.1$ & 2 & -1.0 \\
\hline P. perfoliatus & 4.8 & 2.6 & 2.0 & $2.8 \pm 1.2$ & 3 & -0.8 \\
\hline
\end{tabular}

* no kurtosis calculated, as rooting numbers very low $(\mathrm{n}=2)$

a

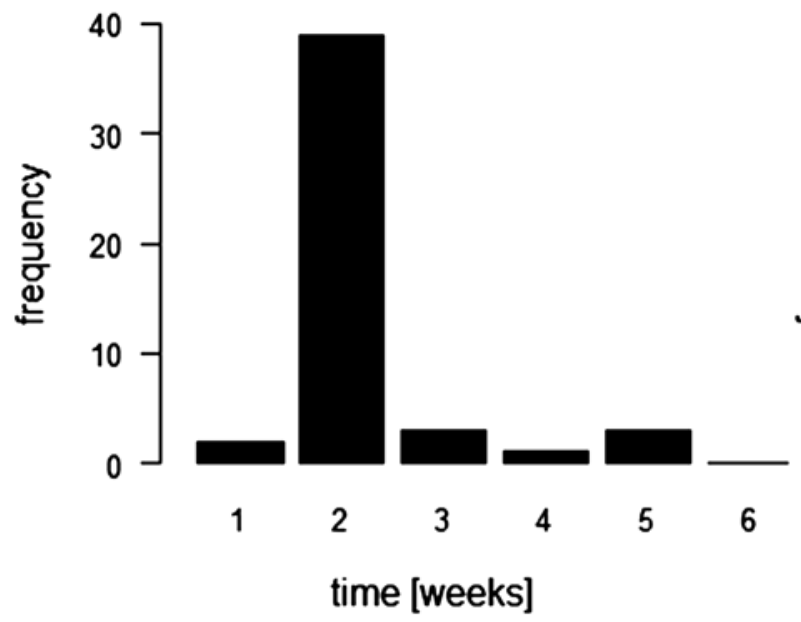

C

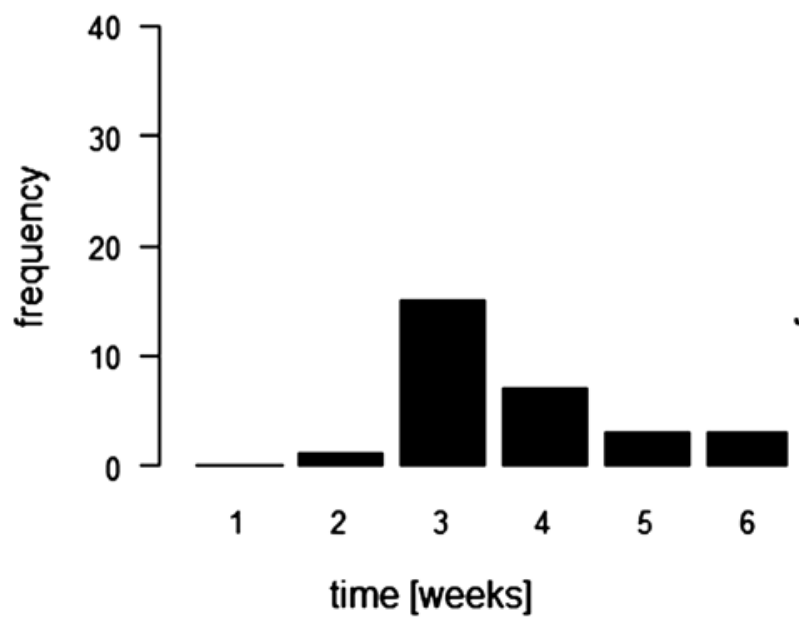

b

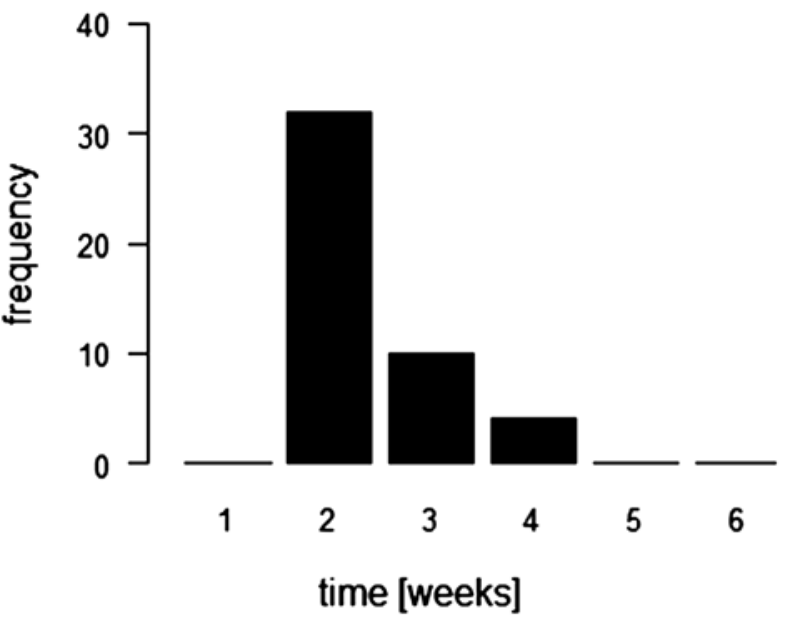

d

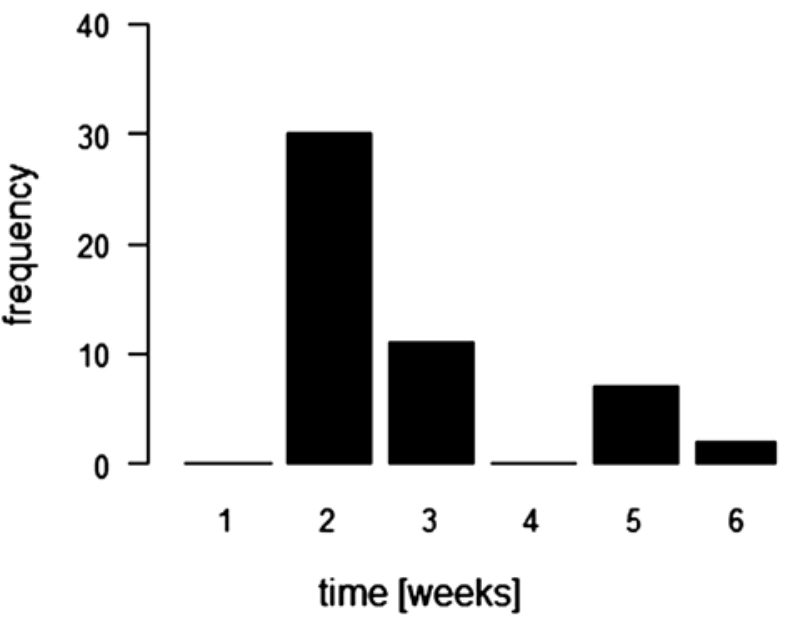

Fig. 2. Histogram of the rooting times (number of observations per week) for different species (a: Egeria densa, b: Myriophyllum spicatum, c: Potamogeton pectinatus, d: Potamogeton perfoliatus). Significant differences between a-c***, a-d $\mathrm{d}^{* *}, \mathrm{~b}-\mathrm{c}^{* * *}$ and $\mathrm{c}-\mathrm{d}^{* * *}$. Differences indicated with $*(p<0.05), * *(p<0.01)$ or $* * *(p<0.001)$. 


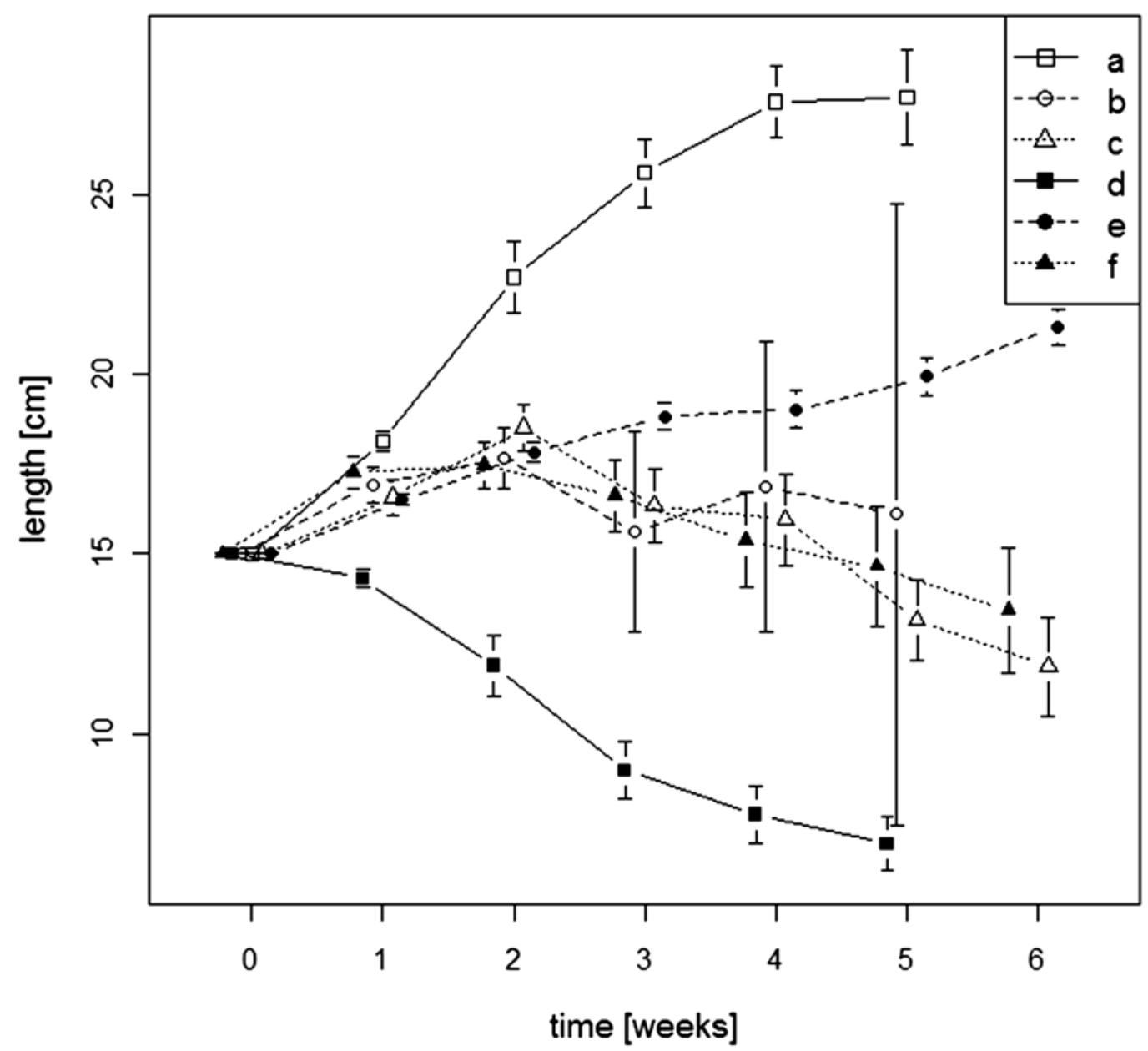

Fig. 3. Development of shoot length for the different species in all three series. a: Ceratophyllum demersum, b: Egeria densa, c: Myriophyllum spicatum, d: Najas marina, e: Potamogeton pectinatus, f: Potamogeton perfoliatus. Following differences tested at week 2 were significant (ANOVA, post-hoc Tukey's HSD): between a-all ***, d-all ***, b-e *, c-e *** and f-e ***. Differences indicated with * $(p<0.05), * *(p<0.01)$ or $* * *(p<0.001)$

distribution. Results in Table 3 show that the value for E. densa is highest, as it rooted very intensely between week two and three, while rooting of P. pectinatus was almost evenly distributed between week two and six and has the lowest kurtosis value.

Differences between species rooting times were significant (Kruskal-Wallis $\left.\mathrm{X}^{2}(4)=50.79, p<0.001\right)$. E. densa and M. spicatum were the most rapid to root, with 2.3 and 2.4 weeks on average (respectively), while P.perfoliatus was slower to root into the sediment (2.8 weeks, significant difference between E. densa and P.perfoliatus on $p<0.01$ level, MannWhitney-Wilcoxon test, for M. spicatum and P. perfoliatus $p>0.05$ ) and rooting of P.pectinatus was significantly slower than of any other species tested (3.7 weeks, Mann-Whitney-Wilcoxon test, all differences on $p<0.001$ level).
Most species showed a distinct pattern of shoot length growth or decline. During the first weeks of the experiment mean shoot lengths usually increased, then started to decrease (Fig. 3). E. densa, P. perfoliatus and $M$. spicatum mean shoot length increased first (after 2 weeks to $17.7 \pm 0.85,17.5 \pm 0.66$ and $18.5 \pm 0.66 \mathrm{~cm}$, mean \pm SE, respectively) and then declined (at the end of the experiment to $16.1 \pm 8.65,13.4 \pm 1.76$ and $11.9 \pm 1.38 \mathrm{~cm}$, respectively). E. densa showed comparatively little growth, however, it has to be noted that as it rooted generally very quickly, most shoots were removed early from the experiment (hence also the great standard errors in Fig. 3). N. marina showed a strong decline in mean shoot length caused by its inclination to fragment (from $15 \mathrm{~cm}$ at the start to $6.9 \pm 0.75 \mathrm{~cm}$ (mean $\pm \mathrm{SE}$ ) after 5 weeks, see Fig. 3 ). C. demersum showed extreme growth (from $15 \mathrm{~cm}$ 
Table 4. Mean of total length growth \pm standard deviation, relative length growth rate of shoot fragments of apical and stem parts after 2 weeks and the difference between growth of apical and stem parts, indicating strength of apical effect.

\begin{tabular}{|c|c|c|c|c|c|}
\hline & \multicolumn{2}{|c|}{ Total growth $\pm \mathrm{SD}[\mathrm{cm}]$} & \multicolumn{2}{|c|}{ Growth rate $\pm \mathrm{SD}\left[\mathrm{cm} \mathrm{day}^{-1}\right]$} & \multirow{2}{*}{$\begin{array}{l}\Delta \text { growth apex-stem } \\
{[\mathrm{cm}]}\end{array}$} \\
\hline & apex & stem & apex & stem & \\
\hline E. densa & $6.8 \pm 5.8$ & $2.4 \pm 5.0$ & $0.48 \pm 0.41$ & $0.17 \pm 0.35$ & 4.4 \\
\hline M. spicatum & $8.0 \pm 4.7$ & $3.2 \pm 3.7$ & $0.57 \pm 0.34$ & $0.23 \pm 0.27$ & 4.7 \\
\hline P.perfoliatus & $6.3 \pm 5.4$ & $-1.1 \pm 2.3$ & $0.45 \pm 0.39$ & $-0.08 \pm 0.16$ & 7.4 \\
\hline
\end{tabular}

Table 5. Numbers of buds/flowers in the three repetitions (mean \pm standard deviation in $\%$ of total fragment numbers).

\begin{tabular}{lcccc}
\hline & series 1 & series 2 & series 3 & mean \pm SD \\
\hline C. demersum & - & $12 \%$ & - & $12 \%$ \\
E. densa & - & $0 \%$ & $0 \%$ & $0 \%$ \\
M. spicatum & $0 \%$ & $10 \%$ & $0 \%$ & $3 \pm 6 \%$ \\
N. marina & - & - & $61 \%$ & $61 \%$ \\
P. pectinatus & $0 \%$ & $0 \%$ & $5 \%$ & $2 \pm 6 \%$ \\
P.perfoliatus & $3 \%$ & $15 \%$ & $10 \%$ & $9 \pm 6 \%$ \\
\hline
\end{tabular}

to almost $27.7 \pm 1.34 \mathrm{~cm}$ on average after 5 weeks). P. pectinatus shoot growth was slow and steady (increase by $6.3 \pm 0.5 \mathrm{~cm}$ after 6 weeks). N. marina and C. demersum differed significantly in shoot length from all the other species (ANOVA for all species $\mathrm{F}(5)=102.5, p<0.001$ and Tukey's post-hoc for all differences $p<0.001$ ), while E. densa, P.pectinatus, P. perfoliatus and M. spicatum formed one group, not differing significantly from each other. For the further weeks an increasing difference between P. pectinatus and the rest of the group can be seen.

The development of shoots was also examined regarding the influence of the two different shoot parts (apex vs. stem) and for influence of season. For all three species with a definite shoot tip (M. spicatum, P. perfoliatus and E. densa) the difference in growth of apical and stem parts was highly significant (ANOVA $p<0.001$ ). Length growth of apical fragments was always greater than that of stems (see Table 4). The effect of apices was greater for P. perfoliatus than the other two species (difference between apical and stem part growth, Table 4; species-shoot part interaction in ANOVA significant at $p<0.01$ ).

Most species' fragments rarely produced new buds during the experiment (Table 5), and these never matured and finally decayed. Only N. marina regularly developed flowers (61\%). C. demersum built a few (12\%) flowers, but no maturation was observed and the flowers decayed.

\section{Discussion}

In this experiment species-specific differences in survival and rooting of shoot fragments were analysed for six common and wide-spread species (Table 6). The effect of apices on rooting rate and length growth was demonstrated. The influence of season was shown for three species. As the separate series were parallel to the climatic seasons (from series 1 in spring, series 2 in summer and series 3 in autumn), it can be assumed that there was either some influence exerted prior to the experiment while growing in the field under natural conditions and/or an influence of the natural light that penetrated through the windows. The latter might be also underpinned by the statistically significant difference found in light intensity for the single series. Experimental conditions were equal regarding day length, nutrient supply, nor was there any ecologically significant variation in temperature (see Material and methods).

Survival rates in the five to six week long experiments were analysed, as the time period of survival defines the chances that the fragment arrives at a site which is possibly favourable for establishing. Survival rates show how well shoots of a species can survive if fragmented, and including newly produced fragments

Table 6. Overview of tested effects (species, series, shootpart) on different features of colonisation (survival rate, rooting rate, length growth). Effects of species tested on whole dataset, of series on "series dataset" with M. spicatum, P. pectinatus and P. perfoliatus, of shoot part on "shoot part" dataset with E. densa, M. spicatum and P. perfoliatus. ANOVA for length growth, Chi-square tests for differences in species survival and rooting rate and logistic regression for effect of series and shoot part on survival and rooting rate. Differences are indicated as n.s. (non-significant), $*(p<0.05), * *(p<0.01)$ or $* * *(p<0.001)$.

\begin{tabular}{lccc}
\hline & species & series & shoot part \\
\hline survival rate & n.s. & $* *$ & n.s. \\
Rooting rate & $* * *$ & $* * *$ & $* *$ \\
length growth & $* * *$ & $*$ & $* *$ \\
\hline
\end{tabular}


in calculations, they reflect the total potential that is ready to colonise new areas. The tested species did not differ significantly in their survival rates, survival was generally rather high, which is also reflected in minimum mean survival times being rather close to the duration of the experimental series. Total survival was complemented by further fragmentation, which potentially increases dispersal.

Previous data on survival of these species is limited. Stem fragments of M. spicatum were previously observed to survive at a somewhat lower rate than in the present experiment (88-97\% vs. $\sim 60 \%$ after six weeks in Barrat-Segretain et al. 1999). In the cited experiment, C. demersum survived to $90 \%$ after six to ten weeks, which is quite comparable to our results of $100 \%$ survival. None of the examined species showed the rapid decline described by Barrat-Segretain et al. (1998) for some species, e.g. Potamogeton pusillus ( $0-50 \%$ survival after five weeks). N. marina had the lowest survival rate, but was still at $83 \%$. Under natural conditions, $N$. marina is rather fragile and seems to produce numerous unrooted fragments (personal observation), but it had also high fragmentation rates in the experiment. Provided that survival rates of fragments are high in the field and fruits can ripen on unrooted plants this might constitute altogether a coherent propagation strategy for an annual macrophyte, ensuring distribution of seeds already prior to seed release, without the need to invest in building new roots.

According to our hypothesis, the rooting rates of species differed significantly. Despite the frequently found descriptions of the quick fragmentation and high colonisation efficiency of M. spicatum (e.g. Aiken et al. 1979, Borbás 1900, Nichols \& Shaw 1986), it was less successful than E. densa and P.perfoliatus. In a similar experiment (Riis et al. 2009), M. spicatum obtained the highest colonisation rates outperforming P. perfoliatus and Elodea canadensis (100\%, $88-92 \%$ and $60-90 \%$, respectively), after only three to four weeks.

Observations on E. densa showed that it is not only very quick to root but also highly efficient. Rooting of E. densa was also characterized by a much greater number of roots than in any other species. The South American native E. densa (Cook \& Urmi-König 1984) is not yet found in Lake Balaton as it is thermophile and thus only present in the inflowing warm water of Hévíz channel (Szabó 2002), with only one further occurrence (also in warm water) known within Hungary (Felföldy 1990). Highly efficient colonisation by E. densa was already described from several sites, where it altered community composition at the expense of native aquatic species, e.g. in California (Sacramento-San Joaquin River Delta, Santos et al. 2011) or in Germany in a thermally polluted river (River Erft, Hussner \& Lösch 2005). Predicted climate change together with this observed efficiency of colonisation may result in the future rapid spread of E. densa in Lake Balaton.

The rather high rates of rooting for most species, but especially for E. densa, P. perfoliatus and M. spicatum, show that colonisation by fragment-rooting is indeed a possible strategy that might be applied under favourable natural conditions.

A difference in rooting activity of fragments with apices and without is probably attributable to the presence (or absence) of the apical meristem, which produces the phytohormone auxine that induces root growth and suppresses branch development (Jiang et al. 2008, Srivastava 2002). Enhanced root growth for apical parts was proved in the present experiment on P.perfoliatus, $M$. spicatum and E. densa.

For these three species the influence of shoot part was highly significant in shoot length growth. Apical fragments usually exhibited a much higher growth than stem parts of the same initial length. This might be due to internodes already set up in the apex, which therefore only needed to be extended, but also to the fact that elongation is regulated by phytohormones produced mainly in the apical meristem (Cao \& Wang 2012a, Srivastava 2002).

Our finding, that apices increase colonisation rates and shoot length growth of P.perfoliatus and M. spicatum, is supported by Riis et al. (2009) (but not for M. spicatum colonisation rate) and Umetsu et al. (2012). Also Cao \& Wang (2012a) found that the presence of apices did not have any effect on root development of M. spicatum, but effects were shown for shoot length growth of $C$. demersum. Obviously, the effect of the apical meristem is stronger in P.perfoliatus than in M. spicatum.

For the three species examined for the effect of seasonality, rooting probabilities were much lower in the first (spring) series of the experiment than in the second (summer) and third (autumn). It would make sense from an ecological point of view that the tendency to propagate and to colonise is generally weakest at the start of the growth period where resources are more needed for quick growth and outcompeting others than for spreading. Several examples in the literature mention late summer or autumn as the preferred period of dispersal and colonisation (e.g. P. pectinatus in autumn (Van Wijk 1989) and M. spicatum during late summer (Kimbel 1982, Nichols \& Shaw 1986, 
Titus \& Adams 1979) or generally submerged macrophytes in late summer (Capers 2003)). Several other seasonal patterns are described by Barrat-Segretain \& Bornette (2000) for different species: the colonisation efficiency of some rises in autumn (e.g. Luronium natans, Elodea canadensis) while season does not seem to be of any influence to other species (e.g. Sparganium emersum). According to the present experiment, M. spicatum, P. perfoliatus and P. pectinatus might be included in the list of species influenced by seasonality in their activity to colonise by re-rooting fragments.

The distribution of rooting time indicates the vigour of colonisation. Again, E. densa was the fastest and combined with its high rooting rate overtook all other species. Similar results were obtained for E. densa by Umetsu et al. (2012) and by Riis et al. (2009) for the closely related Elodea canadensis. Together with E. densa, M. spicatum was among the first to colonise. Fast rooting makes the colonisation of close-by areas possible, while the survival of some non-rooted fragments and slower rooting enhances the probability of long-distance dispersal and colonisation of areas further away.

Shoot length can be regarded to a certain extent as an indicator of shoot vitality. For most species, a decline in shoot length started after two to three weeks, which to some extent can be explained by fragmentation. A decline in mean shoot length had two reasons: one was the decaying of shoot parts (at tip or base), the other was fragmentation. The two species which tended to build the most new fragments ( $N$. marina and $M$. spicatum) had the smallest shoot lengths in the end.

As expected, C.demersum was least affected by fragmentation: it exhibited the highest survival rates and the greatest shoot growth. Cao \& Wang (2012a) remark that $C$. demersum is able to allocate more resources to the development of shoots as there is no need to invest in root structures. For C. demersum it is not the production of generative reproductive features that is relevant but the growth of shoots, as this species mostly reproduces by shoot fragments (e.g. Arber 1920, Sculthorpe 1967).

Fragments of M. spicatum, P. pectinatus or P.perfoliatus rarely built new reproductive structures under experimental conditions and never succeeded in developing them further; they always decayed. Shoot lengths also decreased for M. spicatum and for P.perfoliatus. For these species fragmentation is certainly a major interruption in the life-cycle. The comparatively higher costs of sexual reproduction might possibly be too high to be covered by nutrient uptake from the wa- ter alone. A trade-off between vegetative regeneration and sexual reproduction might be visible here (Chu et al. 2011, Lovett Doust 1989, Obeso 2002). The hypothesis that species well adapted to being rootless would show greater length growth and continue their life-cycle has to be refuted for M. spicatum. It is supposed that despite the fact, that the aquatic environment supports life without roots, for life cycle continuation probably even most of the aquatic plants need to be rooted (e.g. Brock et al. 1989).

Regarding the overall success of survival and rooting of fragments in the experiment (including some species-specific variation), it can be assumed that for most of the tested species, colonisation in the field might indeed take place by this means under favourable conditions. Generally, fragmentation and re-rooting is one of the most efficient forms of spread and establishment for aquatic plants, as the aquatic habitat itself favours the dispersal of shoot fragments (Grace 1993). In rivers it was found that $80 \%$ of individual plants that established originated from fragments (Riis 2008). For Lake Balaton this means that most of the investigated species, but especially P. perfoliatus, P. pectinatus and M. spicatum, would be able to use fragment re-rooting in order to establish new colonies and reestablish denser macrophyte vegetation in the Lake.

Quick establishment via fragments has two sides: on the one hand, it is an important feature aiding restoration of the original lake vegetation. On the other hand, the potential to colonize effectively by fragments may provide species with the potential to become invasive and spread rapidly. Such cases are reported for M. spicatum in Canada and USA (Madsen et al. 1988, Aiken et al. 1979), but also for C. demersum in China (Cao \& Wang 2012a) and E. densa in Canada and the US (Santos et al. 2011). Regarding re-establishment in Lake Balaton, it is especially the colonisation potential of $E$. densa that might be seen as a major threat to the native aquatic vegetation.

It is important to note that when considering lake restoration measurements, both desired and undesired establishment has to be taken into account (Hilt et al. 2006) as well as the species-specific colonization potential and seasonal variations.

\section{Acknowledgements}

The help of E. Oláh, D. Lukács, A. Filla and E. Baranyai in the maintenance of the experiments is thanked as well as B. Németh for performing water chemistry analyses. I am grateful for A. Zlinszky improving the English of my manuscript. E. Gross as well as two anonymous reviewers are thanked for making valuable suggestions regarding an earlier version of the manuscript. 


\section{References}

Aiken, S. G., Newroth, P. R. \& Wile, I., 1979: The biology of Canadian weeds 34: Myriophyllum spicatum L. - Can. Plant Sci. 59: 201-215.

Arber, A., 1920: Water plants. - Cambridge University Press, London, pp. 1-436.

Barrat-Segretain, H. M., 1996: Strategies of reproduction, dispersion, and competition in river plants: A review. - Vegetatio 123: $13-37$.

Barrat-Segretain, M.H. \& Bornette, G., 2000: Regeneration and colonisation abilities of aquatic plant fragments: effect of disturbance seasonality. - Hydrobiologia 421: 31-39.

Barrat-Segretain, M.H., Bornette, G. \& Hering-Vilas-Boas, A., 1998: Comparative abilities of vegetative regeneration among aquatic plants growing in disturbed habitats. - Aquat. Bot. 60: 201-211.

Barrat-Segretain, M.H., Henry, C.P. \& Bornette, G., 1999: Regeneration and colonisation of aquatic plant fragments in relation to the disturbance frequency of their habitats. - Arch. Hydrobiol. 145: 111-127.

Barrett, S. C. H., Eckert, C. G. \& Husband, B. C., 1993: Evolutionary processes in aquatic plant-populations. - Aquat. Bot. 44: 105-145.

Borbás, V., 1900: A Balaton tavának és partmellékének növényföldrajza és edényes növényzete. - A Balaton Tud. Tanulm. Eredm. M. Földrj. Társ. Balaton-Bizottsága, II/2, Budapest, pp. 1-413.

Brock, T.C.M., Mielo, H. \& Oostermeijer, G., 1989: On the life cycle and germination of Hottonia palustris L. in a wetland forest. - Aquat. Bot. 35: 153-166.

Cao, Q.-J. \& Wang, D., 2012a: Fragment growth of rooted and rootless submerged aquatic macrophytes: effects of burial modes and decapitation of shoot apex. - J. Freshw. Ecol. 27: 315-324.

Cao, Q.-J. \& Wang, L., 2012b: Interactions between submerged and floating plant species with different types of nutrient uptake in sand and fertile sediments. - Fundam. Appl. Limnol. 181: $15-24$

Capers, R.S., 2003: Macrophyte colonisation in a freshwater tidal wetland (Lyme, CT, USA). - Aquat. Bot. 77: 325-338.

Chu, S., Zhang, Q., Liu, S., Zhang, S., Tang, J., Lu, Z. \& Yu, Y., 2011: Trade-off between vegetative regeneration and sexual reproduction of Sargassum thunbergii. - Hydrobiologia 678: 127-135.

Cook, C. D. K. \& Urmi-König, K., 1984: A revision of the genus Egeria (Hydrocharitaceae). - Aquat. Bot. 19: 73-96.

Denny, P., 1972: Sites of nutrient absorption in aquatic macrophytes. - J. Ecol. 60: 819-829.

Felföldy, L., 1990: Hínárhatározó. Vízügyi hidrobiológia. 18. - Aqua kiadó és nyomda leányvállalat, Budapest, pp. 1-145.

Grace, J. B., 1993: The adaptive significance of clonal reproduction in angiosperms: an aquatic perspective. - Aquat. Bot. 44: $159-180$.

Hartleb, C. F., Madsen, J. D. \& Boylen, C. W., 1993: Environmental factors affecting seed-germination in Myriophyllum spicatum L. - Aquat. Bot. 45: 15-25.

Herodek, S. \& Lackó, S., 1988: Lake Balaton - Research and management. - Nexus, Budapest, pp. 1-110.

Hilt, S., Gross, E. M., Hupfer, M., Morscheid, H., Mählmann, J., Melzer, A., Poltz, J., Sandrock, S., Scharf, E.-M., Schneider, S. \& van de Weyer, K., 2006: Restoration of submerged vegetation in shallow eutrophic lakes - A guideline and state of the art in Germany. - Limnologica 36: 155-171.
Hussner, A. \& Lösch, R., 2005: Alien aquatic plants in a thermally abnormal river and their assembly to neophyte-dominated macrophyte stands (River Erft, Northrhine-Westphalia). - Limnologica 35: 18-30.

Hutchinson, G. E., 1975: Limnological botany. A treatise on limnology, III. - J. Wiley \& Sons, New York et al., pp. 1-660.

Istvánovics, V., Clement, A., Somlyódy, L., Specziár, A., G.Tóth, L. \& Padisák, J., 2007: Updating water quality targets for shallow Lake Balaton (Hungary), recovering from eutrophication. - Hydrobiologia 581: 305-318.

Jiang, J., An, S., Zhou, C., Guan, B., Sun, Z., Cai, Y. \& Liu, F., 2008: Fragment propagation and colonisation ability enhanced and varied at node level after escaping from apical dominance in submerged macrophytes. - J. Integr. Plant Biol. 51: $308-315$.

Juhász, E., 1981: A Balaton hínártérképezése. - Hidr. Közl. 61: $315-321$.

Kárpáti, I., 1980: A Balaton makrofiton kutatásainak ujabb eredményei. - VEAB Monogr. 6: 5-17.

Kárpáti, I. \& Varga, G., 1970: A Keszthelyi öböl hínárvegetációja kutatásának eredményei. - Keszthely. Keszthely, pp. $1-67$.

Kautsky, L., 1988: Life strategies of aquatic soft bottom macrophytes. - Oikos 53: 126-135.

Kautsky, L., 1990: Seed and tuber banks of aquatic macrophytes in the Askö Area, Northern Baltic Proper. - Holarctic Ecol. 13: 143-148.

Kimbel, J.C., 1982: Factors influencing potential intralake colonisation by Myriophyllum spicatum L. - Aquat. Bot. 14: 295-307.

Lovett Doust, J., 1989: Plant reproductive strategies and resource allocation. - Trends Ecol. Evol. 4: 230-234.

Madsen, J. D., Eichler, L. W. \& Boylen, C. W., 1988: Vegetative spread of Eurasian watermilfoil in Lake George, New York. - J. Aquat. Plant Manage. 26: 47-50.

Madsen, T. V. \& Cedergreen, N., 2002: Sources of nutrients to rooted submerged macrophytes growing in a nutrient-rich stream. - Freshw. Biol. 47: 283-291.

Meyer, D., Dimitriadou, E., Hornik, K., Weingessel, A. \& Leisch, F., 2012: Misc Functions of the Department of Statistics (e1071), TU Wien. - R package version 1.6-1. http:// CRAN. R-project.org/package=e1071.

Nichols, S.A. \& Shaw, B.H., 1986: Ecological life histories of the three aquatic nuisance plants, Myriophyllum spicatum, Potamogeton crispus and Elodea canadensis. - Hydrobiologia 131: 3-21.

Obeso, J. R., 2002: The costs of reproduction in plants. - New Phytol. 155: 321-348.

Présing, M., Preston, T., Takátsy, A., Sprőber, P., Kovács, A. W., Vörös, L., Kenesi, G. \& Kóbor, I., 2007: Phytoplankton nitrogen demand and the significance of internal and external nitrogen sources in a large shallow lake (Lake Balaton, Hungary). - Hydrobiologia 599: 87-95.

Preston, C. D., 1995: Pondweeds of Great Britain and Ireland. - Botanical Society of the British Isles, London, pp. 1-352.

R Development Core Team, 2012: R: A language and environment for statistical computing. - R Foundation for Statistical Computing, Vienna, Austria, http:/www.R-project.org/.

Riis, T., 2008: Dispersal and colonisation of plants in lowland streams: success rates and bottlenecks. - Hydrobiologia 596: 341-351.

Riis, T., Madsen, T. V. \& Sennels, R. S. H., 2009: Regeneration, colonisation and growth rates of allofragments in four common stream plants. - Aquat. Bot. 90: 209-212. 
Santos, M. J., Anderson, L. W. \& Ustin, S. L., 2011: Effects of invasive species on plant communities: an example using submersed aquatic plants at the regional scale. - Biol. Invasions 13: 443-457.

Sayer, C. D., Davidson, T. A. \& Jones, J. I., 2010: Seasonal dynamics of macrophytes and phytoplankton in shallow lakes: a eutrophication-driven pathway from plants to plankton? Freshw. Biol. 55: 500-513.

Sculthorpe, C. D., 1967: The biology of aquatic plants. - Edward Arnold Ltd., London, pp. 1-610.

Silvertown, J., 2008: The evolutionary maintenance of sex: evidence from the ecological distribution of asexual reproduction in clonal plants. - Int. J. Plant Sci. 169: 157-168.

Smith, D. H., Madsen, J. D., Dickson, K. L. \& Beitinger, T. L., 2002: Nutrient effects on autofragmentation of Myriophyllum spicatum. - Aquat. Bot. 74: 1-17.

Srivastava, L. M., 2002: Plant growth and development. Hormones and the Environment. - Academic Press, San Diego, USA \& London, UK, pp. 1-772.

Szabó, I., 2002: Melegvizi növényfajok Hévíz és Kesztely vizeiben. - Bot. Közl. 89: 105-115.

Titus, J.E. \& Adams, M. S., 1979: Comparative carbohydrate storage and utilization patterns in the submersed macrophytes, Myriophyllum spicatum and Vallisneria americana. - Am. Midl. Nat. 102: 263-272.

Submitted: 23 March 2012; accepted: 12 June 2013.
Tóth, V. R. \& Herodek, S., 2011: Seasonal shift of dominance in a submerged rooted macrophyte community of Lake Balaton. - Ann. Limnol. 47: 141-150.

Umetsu, C.A., Evangelista, H.B.A. \& Thomaz, S. M., 2012: The colonisation, regeneration, and growth rates of macrophytes from fragments: a comparison between exotic and native submerged aquatic species. - Aquat. Ecol. 46: 443-449.

Van Wijk, R. J., 1989: Ecological studies on Potamogeton pectinatus L. III. Reproductive strategies and germination ecology. - Aquat. Bot. 33: 271-299.

Virág, Á., 1998: A Balaton múltja és jelene. - Egri Nyomda Kft, Eger, pp. 1-904.

Wersal, R. M. \& Madsen, J. D., 2011: Influences of water column nutrient loading on growth characteristics of the invasive aquatic macrophyte Myriophyllum aquaticum (Vell.) Verdc. - Hydrobiologia 665: 93-105.

Wiegleb, G. \& Brux, H., 1991: Comparison of life history characters of broad-leaved species of the genus Potamogeton L. I. General characterization of morphology and reproductive strategies. - Aquat. Bot. 39: 131-146.

Xie, D. \& Yu, D., 2011: Size-related auto-fragment production and carbohydrate storage in auto-fragment of Myriophyllum spicatum L. in response to sediment nutrient and plant density. - Hydrobiologia 658: 221-231. 